\title{
EAT AND/OR BE EATEN: THE EVOLUTIONARY ROOTS OF VIOLENCE? ${ }^{1}$
}

\author{
Ernst M Conradie \\ Department of Religion and Theology \\ University of the Western Cape
}

\begin{abstract}
This contribution raises the question about where things have gone wrong in evolutionary history. In classic Christian discourse it is typically assumed that the primary problem is human sin, while the problem of natural evil is emphasised elsewhere. It seeks to test the distinction between natural suffering and sociallyinduced forms of suffering by exploring the roots of violence between species with reference to the emergence of the act of eating in evolutionary history. It draws on a corpus of recent literature on the consumption of food, with specific reference to the work of Edward Farley, Sallie McFague and Norman Wirzba, in order to address the following question: Is the violence associated with what Christians would redescribe as sin merely an extrapolation of the 'violence' embedded in the act of eating? The conclusion from this survey seems to be that an Augustinian approach is indeed less plausible and more counter-intuitive than Manichean or Pelagian assessments of where things have gone wrong in evolutionary history. If so, this would have far-reaching consequences for moral formation. The conclusion is offered here in the hope that it would be refuted by others!
\end{abstract}

Key Words: Evolution; Food; Violence; Human Sin; Edward Farley; Sallie McFague; Norman Wirzba

\section{Where have Things gone wrong in Evolutionary History?}

Where have things gone wrong in the evolution of life on earth? Is there a sense in which nature too has to be redeemed (irrespective of human impact), for example with reference to the brutality that characterises relationships between non-human animals? Would a Christian emphasis on human sin as the root of evil not underestimate the problem of natural suffering, even where it is allowed that human pride, greed, subjugation, alienation and moral failure have greatly exacerbated such suffering? What exactly is the problem from which the world has to be saved? Consider the following possibilities as to where things may have gone wrong: ${ }^{2}$

- Contingency and chance in a world in flux that is not characterised by some eternal essence. Does God play dice? Is salvation then the eradication of contingency?

- Entropy and the arrow of time implying the transience of everything in the universe

This article is based on a paper delivered at a conference on "Re-imagining the Intersection of Evolution and the Fall", Garrett-Evangelical Theological Seminary (Evanston, IL), 26-28 March 2015.

2 More or less the same list may also be found in my Saving the Earth? (Conradie 2013b:19-20), in a section that explains the difficulty of doing justice to both God's work of creation and of salvation. See also an essay on "Darwin's ambiguous gift to reformed theology" (Conradie 2013a:100-101). 
(including stars, planets, continents, mountains and rivers). The cosmological transience of the earth itself - which is destined to melt away when the sun becomes a supernova in about 5 billion years' time. Is salvation then 'eternal' salvation from temporality?

- The very basis of biological functioning in terms of living organisms absorbing inorganic materials. Eating organic leftovers (like fruit and nuts). Eating living organic material (grass, vegetables). Eating other living organisms (meat). Does 'eternal' life still imply eating and the violence embedded in such eating? Is eternal life then still a form of life?

- The pre-programmed, limited life cycle of multi-cellular organisms and their cells (planned obsolescence). Aging, vulnerability, fragility, degeneration and the decay of possibilities. The eventual mortality of every form of life but also of species. Is death God's own doing? Is salvation then to be understood as biological perfection or longevity?

- The contingency, dead-ends, chaotic and experimental nature and incredible wastefulness of evolutionary drivers. Does God support the survival of the fittest?

- Pain impulses. Sentient suffering. Anxieties over the possibility of future suffering among the 'higher' mammals. Is the very notion of God perhaps born from (human) anxiety over finitude (in the form of vulnerability together with limited power and knowledge)? Are we to be saved from such anxiety? Would it help if all tears were wiped from our eyes?

- Killing for food. Excessive violence, brutality and 'torture', also among non-human species. Are 'selfish genes' inscribed in God's good creation? May mammals terminate other forms of life (also vegetables) to obtain food for themselves as long as this is done without brutality? Are we only saved from excessive brutality so that the violence embedded in most forms of eating is maintained, also eschatologically? Did the resurrected Christ not eat fish on the beach?

- (Only) the destructive presence of humans in ecosystems. Is nature only to be redeemed from anthropogenic destruction? Is sin (and the evil effects of sin, especially in terms of structural violence) our only problem? Is it only unnecessary suffering, imposed deficiencies and premature death that are to be avoided, while other forms of natural suffering are to be embraced, also eschatologically?

In Christian theology it was traditionally maintained that the primary problem from which the world needs to be saved is human sin (i.e. only the last one mentioned in the list above). Accordingly, all other forms of suffering are related to the accumulated results of human $\sin \left(\right.$ structural violence $^{3}$ ). The wages of $\sin$ is death (Rom 6:23). However, given insights from evolutionary biology, this position can hardly be maintained. Pain and death have formed part and parcel of sentient life throughout evolutionary history.

Those who still wish to claim that mortality (as distinct from 'death' as alienation from God) is the result of sin would need to argue against ample scientific evidence of sickness

The term 'original sin' is best used not as an account of the origins of sin but for the planetary consequences of sin that have become 'universal' and inescapable. The term structural violence is a secular equivalent in that it describes a situation is which all human beings (and other forms of life) are caught, under which they suffer (albeit not equally so) and to which they have contributed (again not equally so). There may well be consensus on the universality of $\sin$, if not on an explanation as to why sin has become so universal (Durand 1978:126). It should be noted that, given this misnomer this contribution therefore does not contribute to literature on evolution and 'original sin'. For a recent discussion, see Edwards (2014:130-146). 
and death amongst other species long before there were human beings on earth. As Gijsbert van den Brink (2011:765) observes, "Death and decay, suffering and starvation have been part of the natural world long before humanity appeared on the scene so that nature did not 'fall' into such a state as a result of human behaviour ... we human beings ourselves seem to have been aggressive savages from the very beginning of our existence. Rather than having fallen it seems that we were 'created fallen'." Although the fall as a singular historical event may need to be 'dropped', one may still wish to retain something like the Christian category of sin to redescribe forms of violence that may be regarded as inappropriate, excessive, unnecessary or downright evil. This indicates the need for and the possibility of moral judgements.

In twentieth century theologies that have recognised evolutionary insights one finds a widespread recognition that (human) finitude implies forms of vulnerability, fragility, pain, suffering and mortality. Such finitude, it is widely asserted, is not the result of sin but forms part and parcel of biological existence. Re-described in theological categories, finitude is a dimension of God's good creation and is implied in the very distinction between Creator and creature. Human finitude has several dimensions, including limited power and knowledge and the anxiety that this induces, but also a sense of transience (perpetual perishing), mortality and the anxiety that this induces, also in perfectly healthy organisms. ${ }^{4}$ Accordingly, the experience of pain is an evolutionary advantage in sentient organisms, while sickness and death form an inevitable part of biological functioning. The suffering implied therefore cannot be attributed to the consequences of human sin although it may certainly be aggravated by sin. Biological evidence for mortality is therefore theologically accepted as God's doing, even as God's gift to creatures. As Arnold van Ruler (2008:301) puts it metaphorically, if the leaves fell from the trees in the Garden of Eden, death was already present in God's good creation.

I would concur with such a theological affirmation of pain, suffering and mortality as part of the created order. Clearly, a distinction between mortality and death as judgement and alienation from God is required (see Jüngel 1971). Likewise, a distinction between pain impulses and experiences of injustices is necessary. This suggests the need for a distinction between so-called natural suffering (sometimes described as 'natural evil') and sociallyinduced suffering (social evil) that is found widely in contemporary literature (see, e.g. Drees 2003). ${ }^{5}$ The difficulty with this distinction is that human beings form part of nature so that the human ability to sin originates in the evolution of life (Gestrich 1997:146). Yet, the distinction may help humans to distinguish between evil (and suffering) that can be avoided and that which cannot be avoided, what we need forgiveness for and what we need to come to terms with.

Such a distinction between natural suffering and socially-induced suffering allows one to focus on the primary social problems that are presumably caused by human sin, such as economic injustices, violent conflict and anthropogenic environmental destruction (implied in the ecumenical call for "Justice, Peace and the Integrity of Creation"). Such issues are

For the distinction between the predicaments of sin (and the evil consequences of sin), finitude in time (mortality and transience) and spatial finitude (the limits of human knowledge and power), see Conradie (2005).

5 In German a distinction is made between Böses (human guilt) and Übel (natural evil). Leibniz already distinguished between moral evil (human sin), physical or natural evil (suffering) and metaphysical evil (the imperfection of things). For Leibniz, moral evil is the result of metaphysical evil, while suffering (natural evil) follows from moral evil. For others, human guilt follows from natural suffering so that humans incur such guilt as victims. For a discussion, see Gestrich (1997:145-150). 
addressed in many contemporary theologies including liberation theology, feminist theology, black theology, eco-theology and so forth. Put differently, our primary problem is not vulnerability but rape, not service but slavery, not death but murder, not sickness but the spread of preventable diseases, not economic scarcity or even inequality but capitalism, not being ruled but Empire, not the evolution of species but the loss of biodiversity, not an always changing climate but anthropogenic climate change, not hunger due to inadequate food production but due to its skewed distribution and/or the over-supply of fast food with high-sugar and high-fat contents. Accordingly, such forms of oppression, subjugation and evil are not necessary, can in principle be avoided and therefore should be resisted.

By contrast, in other forms of theological discourse (especially in conversation with the so-called 'natural' sciences) there is (in my view) an unhealthy interest in natural suffering as seemingly the primary problem that has to be confronted. The presence of social forms of evil is acknowledged, if not taken for granted, but the intriguing problem of natural suffering often dominates debates. This leads to an acute interest in the theodicy problem (justifying God in view of natural suffering) instead of the required interest in liberation from oppression, forgiveness for guilt and complicity, reconciliation amidst alienation and victory over evil. ${ }^{6}$

In some secular discourses there is a temptation to minimise human accountability for evil and to treat humans as the 'innocent' victims of forces beyond their control. This pathologises evil according to the dominant cultural trends where 'remedies' may be prescribed to overcome 'diseases' in 'patients'. Of course this cannot and does not take away legal accountability or social and political responsibility so that the roots of such evil remain contested. However, one also finds a temptation to treat the material reality, being embodied and the need for consumption, ${ }^{7}$ with Manichean (if not anorexic) disdain so that the suffering embedded in evolutionary history itself becomes the primary problem from which we have to be rescued, presumably in a radically 'new creation'.

In this contribution I will test the distinction between natural suffering and sociallyinduced forms of suffering by exploring the roots of inter-species violence with reference to the emergence of the act of eating in evolutionary history. I will draw on a corpus of recent literature on the consumption of food, especially in the context of Christian eco-theology, in order to address the following question: Is the violence associated with what Christians would redescribe as sin merely an extrapolation of the violence embedded in the act of eating? In other words: Is there a way in which eating can be understood without such violence - so that the Protestant intuition that sin is the root cause of evil can be maintained? Can the focus on economic injustices, violent conflict and anthropogenic environmental destruction as the primary problems that have to be addressed then be maintained?

Given this focus on the relationship between natural suffering and socially-induced forms of suffering I cannot assume any all too tidy distinctions between animals and human animals, nature and culture, biological evolution and cultural evolution, facts and values,

For a critique of such positions, see Conradie (2006).

For Martin Versfeld an appreciation for the material is the equivalent of the spiritual. He states: "The good life, then, is ... where the water or wine we drink ... has not lost its corporeality because it is the eternal drink which will take away all thirst. Hence we talk of tasting life, of tasting God, the gustation of God, when our flesh and blood call for the Living God - our flesh and blood, not a meagre spiritual ego born of desire and abstraction and attempting to nourish itself on the thin soup of success" (1983:17). And: "Eating is not only a physical process; it is also a spiritual process. Your food could not enter your mouth did it not first enter your mind. You are what you eat, but you also eat what you are. You pour a spiritual sauce on what enters your mouth, like an act of sex which is clothed with imagination" (1983:52). 
pre-moral awareness and moral awareness - since such assumptions are precisely under investigation. There is obviously some discontinuity between these pairs - so that it would be reductionist to equate violence amongst humans with violence in the form of predation between non-human species. Be that as it may, there is clearly also some continuity here. It is the significance of this continuity that will be assessed here. To say that something has gone 'wrong' in evolutionary history is therefore not necessarily a moral judgement since that would assume that things have only gone wrong with the emergence of moral agents which presumably applies only to human beings but not to all human beings (infants, the insane, the comatose and the senile need not be regarded as morally accountable). What has gone 'wrong' could also refer to weather cycles, the scarcity of resources, viral infections, cancer and so forth. Likewise, the term 'violence' has to be used here in a minimalist sense. It does not necessarily entail moral agency or even intentional agency. Violence may be understood provisionally as harm done by one metabolism to another metabolism. ${ }^{8}$ This is exemplified by predation and the act of eating, but is also applicable to parasites.

The category of 'sin' is in my view best regarded as a religious and more specifically a Christian redescription of what has gone wrong in the world. It would be reductionist to regard sin as a moral category only - as it includes connotations of a relatedness with God. However, sin clearly also includes moral connotations. Likewise, a moral judgement cannot be reduced to a biological or medical diagnosis of what has gone wrong, but it is not unrelated to biological and environmental categories either. How, then, is the act of eating (maintaining a metabolism) related to a theological redescription of what has gone wrong in the world in terms of human sin?

\section{How is Eating related to Human Sin?}

The distinction between natural suffering and social evil seems to underplay the 'violence' associated with eating. This is expressed in the saying 'eat or be eaten' captured in the title of this contribution. Technically, one should say eat and be eaten since all organisms that eat are eventually eaten themselves (admittedly with some exceptions such as cremation the refusal to be eaten). For some 'eat or be eaten' expresses the law of the jungle where only the fittest survive, for others the golden rule of corporate America and for yet others the name of a board game, a Japanese homoerotic novel or a topic in National Geographic. If eating necessarily implies violence, can the contingency of sin be defended? Or is sin merely an extrapolation in human evolution of forms of violence that are deeply embedded in evolutionary history?

One may argue that amongst humans eating does not necessarily entail violence or killing. Eating is necessary for multi-cellular organisms but predation is only necessary for

For a remarkable phenomenological description of the absorption of food by plants and animals, see Jonas (1966:102-104). All living organisms require continuous self-renewal through the metabolic process. Plants dissolve and absorb nutrients through their roots by a process of osmosis. By contrast, animals require a mechanical stage of conveying and shredding before the direct chemical stage of metabolic appropriation. Through their roots plants are relieved of the necessity of movement, while such mobility enhances the freedom of animals but this implies a more precarious metabolism, an inability to become fully integrated in its environment and a temporal discontinuity between need and satisfaction. This gap between animal organism and environment is spanned by the role of perception, emotional embeddedness and mobility. All animal life is therefore parasitic on plant life. Jonas comments: "Thus animal metabolism makes mediate action possible; but it also makes it necessary. The animal, feeding on existing life, continually destroys its mortal supply and has to seek elsewhere for more. In the case of flesh-eaters, whose food is itself motile, the need is increased in proportion and forces the mutual development of that agility in which so many other faculties of the animal must participate" (p. 105). 
carnivores; others can rely on organic leftovers (e.g. seeds, fruit and nuts). ${ }^{9}$ Eating fruit that fell from the tree hardly involves killing other living organisms (plants or other animals), terminating the functioning of their metabolisms. At most such eating prevents the ability of such seeds to reproduce but even that is not necessarily the case: one may eat an apple and in the process help distribute its seeds. In any case, given the conditions of spatial finitude, not every acorn produced in one season can become a full-grown oak tree. One may condone eating the eggs of some birds on the same basis. In the case of grains (maize, wheat, rice, corn), a one-year plant is perhaps cut prematurely to harvest its seeds but it seems that violence remains restricted. The growth of some plants may be stimulated by cutting (and eating) their leaves so that some symbiosis is possible between herbivores and the plants on which they feed. It is a different matter with vegetables and roots - where the carrot has to be uprooted in order to be eaten. To grow fruit and vegetables also require some pest control regarding insects, snails and rodents.

The real difficulty comes with eating other living organisms in the form of fish or meat. The issue here is not so much a plea for self-induced vegetarian or vegan diets amongst humans (see Grumett, \& Muers 2010), but that human eating habits are in continuity with a long lineage of carnivores and omnivores. Hunting and fishing (and not only gathering) evidently formed part of the earliest human cultures so that the consumption of food is governed by the relationship between predator and prey. Hunting may be said to be beneficial for both predator and prey, but this assumes the need for killing and an acceptance of the need for the survival of the fittest. Numerous studies in animal ethology have rightly pointed out that an emphasis on competition is one-sided since relationships within and between species are also characterised by symbiosis, cooperation (for hunting!) and also compassion. Animals rarely kill except in hunger or self-defence. When they threaten it is precisely for the sake of avoiding combat. ${ }^{10}$ However, the role of hunting and preying in food consumption can hardly be denied. In early hominid evolution eating meat evidently contributed much towards the proteins necessary for growth in brain size. Vegetarian or vegan eating habits are now possible, but humans would not have evolved without hunting for meat.

Such eating entails killing and induces anxiety amongst those sentient animals that are to be killed and swallowed. If so, this raises deeper theological problems. Are we to be redeemed from eating meat and fish? Should all carnivores confess their sins and change their ways, as the imagery in Isaiah 11 seems to suggest? Should herbivores refrain from eating living plants and restrict themselves to organic leftovers from fallen leaves and dead plants? Would this make any sense in terms of evolutionary history? Moreover, is it not a fallacy to assume that not eating meat can avoid the death of other organisms through gardening (including vegetables, micro-organisms and killing rodents and other 'pests')? Why are the lives of other animals regarded as more precious than the lives of plants and other organisms? Does this not re-introduce hierarchical thinking with humans at the top of

9 Admittedly, a world without carnivores is hard to imagine. Holmes Rolston (1994:213-214) rightly insists that "Even grazers are predators of a kind, though what they eat does not suffer. Again, an Earth with only herbivores and no omnivores or carnivores would be impoverished - the animal skills demanded would be only a fraction of those that have resulted in actual zoology - no horns, no fleet-footed predators or prey, no fine-tuned eyesight and hearing, no quick neural capacity, no advanced brains. We humans stand in this tradition, as our ancestors were hunters. We really cannot envision a world, on any Earth more or less like our own, which can give birth to the myriad forms of life that have been generated here, without some things eating other things."

10 See for example the classic study by Mary Midgley (1995), especially the chapter on "Animals and the Problem of Evil”' (pp. 25-49). 
the food pyramid? To assume that eating does not imply death may well hide a Gnostic if not a Manichean tendency, a refusal to accept creation on God's terms (Wirzba 2011:135).

If eating inevitably involves killing, is a sharp distinction between the suffering embedded in evolution and that which is induced by sin still possible? Put succinctly, is human sin merely a way of aggravating the violence that is embedded in evolutionary processes and expressed through the need of complex organisms to obtain food through eating? If so, nature is then included in the fall of humanity, not merely in terms of the impact of sin but also in the gradual progression of falling in sentient, mammalian, hominid and human evolution. Then nature and evil, creation and fall become conflated so that the contingency of sin is abandoned. Falling is unavoidable, indeed inevitable.

One may still argue that all human forms of eating are historically embedded in societal structures that have greatly exacerbated violence. This has developed in line with population growth and conflict over resources. Agriculture was necessary to accommodate such population growth and was enabled by human cooperation, but it also aggravated the nature and scale of conflict between societies. This line of thinking would allow and indeed invite a critique of the injustices and inequalities underlying the production, distribution and consumption of food (the elitism of eating fruits and nuts, the transport of vegetables out of season, commercialised meat production, the undermining of soil fertility through the use of irrigation, fertilisers and pesticides, etc.). ${ }^{11}$ The Protestant intuition is that these are the primary problems to be addressed and that the way eating is portrayed in the previous paragraph remains hypothetical since it is abstracted from current economic systems. Nevertheless, the danger is that capitalist food systems can justify their practices precisely in the name of a survival of the fittest: Eat or be eaten!

Another way of addressing such problems, going back a few billion years in evolutionary history to the earliest forms of life, is to consider the patterns through which bacteria sustain themselves. Three such patterns emerge: Parasitic bacteria feed themselves by killing their hosts. Others live in their hosts but help their hosts, for example to digest food. Some heterotrophic bacteria absorb dead organic material such as decomposing leaves and flesh. By contrast autotrophic bacteria create their own food. Some autotrophs feed themselves through photosynthesis, i.e. by using sunlight, carbon dioxide, water, metallic elements such as calcium, potassium and sodium and other chemicals such as nitrogen, ammonia, phosphorus and sulphur to synthesise food and to release oxygen in the process, while others perform chemosynthesis.

From a theological point of view this raises the possibility of locating the fall from grace within early evolutionary history, i.e. the emergence of parasitic bacteria that not only live off their hosts but also kill their hosts in order to obtain food. Is God therefore responsible for allowing such parasitic bacteria to emerge so that humans and other omnivores may claim that their way of eating is God's doing, according to their Creator's will?

Let me pause here for a moment to consider the theological questions that are at stake:

It is clear on the basis of evolutionary biology and studies on animal ethology that prehuman evolution is characterised by a capacity for both conflict on the basis of selfinterest and cooperation. ${ }^{12}$ Both are illustrated by eating patterns: killing others for food,

\footnotetext{
11 A discussion of such problems related to the production, distribution and consumption of food is found widely in the literature on contemporary Christian eco-theology. See, for example, Northcott (2007:232-266),

Wallace (2010:77-97), Wirzba (2011:71-109)

12

Denis Edwards (2014:142) rightly observes that, amongst humans, cooperation is not necessarily virtuous (we
} 
cooperating with others in doing so and providing food for others (for off-spring and micro-organisms living inside an organism but also through the death of any organism). It is also clear from human history that we have a capacity for compassion and conflict, for forming social contracts and for structural violence that victimises others (and not only human others). Again both are illustrated by the production, distribution and consumption of food in the wake of the agricultural and industrial revolutions. There is clearly some continuity between pre-human evolution and further developments in human history. There is also some discontinuity that may be associated with the emergence of consciousness, self-consciousness and symbolic consciousness, with the evolution of various degrees of freedom, with a sense of anxiety over finitude, with the emergence of forms of culture, religion, and complex societies that allowed for further population growth.

The Christian category of sin has been used to capture and redescribe this discontinuity by indicating what is wrong in the world, to identify the roots of evil and to judge the interplay between compassion and conflict. The moral assessment is clear: things are not what they could be and should be. On this assessment there might well be consensus between different brands of Christianity, different religious traditions, social analysts and secular critics alike.

However, within Christianity itself, there have emerged rather different ways of interpreting this assessment, leading to very different ways of telling the story of creation, sin and salvation. ${ }^{13}$ Historically, the Augustinian version of the story has been dominant. One may say that it is built on four core intuitions, namely a sense of original righteousness (based on an affirmation of the goodness of God's creation), the contingency of the fall as an event in history (expressed in the motto of posse non peccare), ${ }^{14}$ the inescapable impact of sin and evil (expressed in the motto of non posse non peccare) - prompting a recognition of the need for God's grace (salvation understood as God's work, not as ours, in Christ extra nos and through the Spirit in us). Amongst those who affirm the Augustinian version of the story, despite its inherent inability to explain the origin of $\sin ,{ }^{15}$ some of the details of Augustine's position are deeply contested and even widely discarded, e.g. the literal interpretation of Genesis 1-3, the historicity of Adam's fall, the assumption that mortality is the result of the fall, the transmission of guilt through sexual intercourse and the quasi-material understanding of grace. Nevertheless, both the historical contingency and the contemporary inescapability of sin are maintained in order to affirm human complicity for the many manifestations of evil in society. This is held together by the notion of the fall as a historical process, if not as an isolated punctiliar event. If creation and fall are not regarded

can cooperate in economic exploitation), while self-affirmation is not necessarily a vice (it can be based on a sense of dignity, it can aid an exercising of moral conscience and can help to resist conformity). God's economy". See Conradie (2015).

14 See the comment by Cornelius Plantinga (1995:88): "Sin is an anomaly, an intruder, a notorious gate-crasher. Sin does not belong to God's world, but somehow it has gotten in."

15 The classic Augustinian position rejects both dualist explanations (a rival power as the cause of sin - which undermines God's sovereignty) and monist explanations (which render God ultimately responsible for human $\sin$ ). Instead sin is regarded as incomprehensible, as something that should not have been, could not have been but nevertheless is. The problem is that sin is either rendered impossible by the created perfection of human beings (implying their presumed original righteousness) or is made inevitable by the recognition of some inherent flaw that renders them vulnerable to temptation (which ultimately makes God responsible for sin). As Williams (1985:209) observes, "The classic doctrine is impaled on the first horn of the dilemma (original righteousness excludes sin), while modern theological reconstructions are confronted with the other (to acknowledge a flaw seems to equate finitude with sin." 
as separate historical events, then the contingency of sin is lost - so that Manichean dualism or Pelagian optimism seems to be the only viable options (see Williams 1985:213).

Can this Augustinian approach be maintained in the light of the violence associated with eating - i.e. given the continuity between pre-human evolution and the contemporary interplay between compassion and conflict? In other words: Can the contingency of human sin be maintained in the light of the violence embedded in evolutionary history - which is for example manifested in predation and most forms of eating ? $^{16}$ And can the Protestant emphasis on sin as the primary problem at which the message of salvation is directed (leading to a confession of sin) still be maintained in the light of our evolutionary heritage? In short then: is the Augustinian posse non peccare plausible given the functioning of predation in the food chain? ${ }^{17}$

One may well raise the question whether a Manichean approach is not more plausible in order to recognise the inevitability of forms of violence in evolutionary history? Such an approach is not easy to avoid once the continuity of violence associated with eating throughout evolutionary history is recognised. In response to this recognition, one may follow different routes, including the hope for Gnostic forms of redemption that eschew embodiment altogether through an escape into virtual reality, social Darwinism that legitimises the struggle for the survival of the fittest in a neo-liberal capitalist context, a pathologising of evil that seeks therapy for the always innocent victims of evil, or even a return to authoritarian military rule to minimise the violence associated with conflict or to protect access to scarce resources. One may also argue that the world is not necessarily evil, but that there is at least a tragic dimension in all forms of life - for which human beings are not responsible - and which requires a distinction between goodness and perfection. This tragic aspect entails vulnerability, finitude and anxiety but cannot be equated with sin. This is indeed the line followed by many contemporary theologians but it is not clear (to me) whether this can be reconciled with an Augustinian approach. This seems possible only if killing for food is underplayed.

Alternatively, is a Pelagian approach not even more plausible in the light of evolutionary history? This will allow one to affirm that there is indeed "something good in everything I see" and that this helps one to "cope with anything" (as ABBA sings in "I have a dream")? Does the good not outweigh evil, despite the tendencies towards violence that may also be found in each human and indeed in other animals? Should we not rather

16 As Gijsbert van den Brink (2013:772) notes, "if sin is a historically contingent rather than a metaphysically necessary phenomenon, it is not bound up with human nature and therefore we can in principle be liberated from it without losing our humanity."

17 While Theophilus of Antioch believed that predation resulted from the fall, Augustine in fact argued that it was simply an aspect of the created order that one animal is the nourishment of another. To wish that it were otherwise would not be reasonable. Likewise, Thomas Aquinas criticised those who thought there had been no predation among animals before the Fall. The question is nevertheless whether human sin may be regarded as an extrapolation of the violence embedded in predation. Bimson (2006:73) concludes that, "Unlike many in the modem West, estranged from nature and inclined to sentimentalise it, the Hebrew poets had no problem with the natural world's being the way it is. They were fully aware of nature's redness in tooth and claw, and its apparent wastefulness, but did not find this incompatible with belief in a wise and loving Creator; they thus saw no need to invoke a 'cosmic fall' to excuse those aspects that we find offensive." Indeed, it is the wisdom of Qoheleth that prevails: "There is nothing better for mortals than to eat and drink, and find enjoyment in their toil. This also, I saw, is from the hand of God; for apart from him who can eat or who can have enjoyment? For to the one who pleases him God gives wisdom and knowledge and joy; but to the sinner he gives the work of gathering and heaping, only to give to one who pleases God. This also is vanity and a chasing after wind" (2:24-26, NRSV). This may well be sound counsel, as long as it is recognised that, in an evolutionary context, eating also implies being eaten! 
embrace our mixed evolutionary heritage, the inclinations towards compassion and towards conflict, so that we need to muster the forces of goodness in us (emphasising the human will on the basis of the emergence of human freedom) in order to overcome evil, with some help from the 'medicine' of God's grace, if not with the appropriate management of the best available technologies? Does it not make more moral sense to save ourselves and to emphasise our capabilities for doing so? Should we not heed the activist calls to "save the earth" from anthropogenic destruction, relying on our collective efforts to do so? Or, more pessimistically, do we have to do the best we can under the circumstances in order to create a somewhat better world, with some guidance from God's Word? One may then interpret the fall as the inability to rise towards a higher vision (not a fall from a pristine beginning) that became possible through the emergence of human freedom. In other words, is the Christian dialectic between being created in God's image and the fall not best understood as a symbolic rendering of our ambiguous evolutionary past that is constituted by both our genes and our cultural heritage? ${ }^{18}$

If so, although creation and fall may become conflated here (so that 'sin' is regarded as more or less inevitable, even as necessary), unlike classic Pelagian positions where sin is regarded as purely contingent so that it is possible to avoid sin, human freedom can still be affirmed in evolutionary terms, following the emergence of self-consciousness. In revised Pelagian terms sin then has to be understood as our inability/unwillingness to do the best we can to make the world a better place, while salvation is probably best regarded in terms of the imitation of Christ's inspiring kenotic example. This will help to emphasise our genetic tendency towards compassion rather than conflict. In other words: eating (and killing) others may be condoned as long as this is done with limited violence, for the sake of altruism and as long as one allows oneself to be eaten in the end.

In the subsequent discussion I will investigate three paths to address the question as stated above, namely: Is the violence associated with sin merely an extrapolation of the 'violence' embedded in the act of eating? The subtext of this question is whether a Manichean or Pelagian approach to address this question is not more plausible than an Augustinian one. ${ }^{19}$

\section{The Human Condition: Striving for Food}

In his book Good and Evil: Interpreting a Human Condition (1990), the late Edward Farley maintains an Augustinian intuition that sin is best understood as a distortion of reality and more specifically of three overlapping spheres of human reality that he identifies and describes, namely the inter-personal, the societal and individual agency. He argues that the tragic character of human existence is given under the conditions of finitude and that wellbeing, together with aspects such as creativity, affection and the experience of beauty, are only possible and are interdependent with situations of limitation, frustration, disappointment, vulnerability, challenge and suffering (p. 29). He argues that sin cannot be identified

18 See the comment by Philip Hefner (1993:139), "What we have called sin is inherent in human being because it is a constituent of the process that makes life possible in the first place and that contribute to life's development. Thus, even though we are aware of sin and feel its pain (guilt), sin is not present because of some prior evil action or evil nature. The guilt is better understood as a response to our inherent inability to satisfy all the messages that are delivered to our central nervous systems, rather than as a response to an evil act committed in primordial past of the race."

19 The other available options would be to condone the survival of the fittest along neo-Darwinian or Nietzschean lines, or to radicalise an ascetic prescription, namely to become food for others sooner rather later. 
with the tragic dimension of our phylogenetic heritage (our vulnerability to injury, disease, pain, degeneration and death), our social needs and vulnerabilities or the very fact and act of individual consciousness. That would be tantamount to Manicheism (p. 61). Sin, however, is also not purely related to the realm of consciousness or the subject. That would amount to dualism (p. 77). What is evil is not the body, the personal and the social, but evil appropriates and corrupts all these spheres.

In a chapter on "The biological aspect of personal being" Farley describes 'striving' as the most general feature of the human biological condition. Humans have to cope with a dangerous environment where they have to avoid what could prey on them, harm them and compete with them. We strive for nourishment and space and against whatever may interfere or withhold what is needed. We have survival-oriented needs for fresh air, water, food, warmth and safety and genetically rooted tendencies for reproduction and acceptance that are clothed in cultural wrappings (pp. 89-91). Such needs and tendencies imply a degree of aggression to resist, defend and oppose where need be. However, Farley maintains that there is a distinction between benign and malignant aggression (pp. 92, 94) so that such aggression (self-assertiveness if not anger) is not by itself an expression of human sin. There is no one-way causality between genes and behaviour since that would ignore the role of flexibility, human self-transcendence and acculturation (p. 93). We are biochemically equipped to maintain the conditions of our existence so that our biology disposes us towards a range of satisfactions and to oppose whatever threatens that (p. 95). That forms part of what Farley calls 'tragic existence' (the inescapable interplay between satisfaction and suffering) under the conditions of finitude - which can become distorted but should not be conflated with evil. Sin is therefore a contingent and malignant expression of such striving. ${ }^{20}$

For Farley, human evil therefore has a distinctive dynamics that is different from tragic existence and its vulnerabilities and from the dynamics of pathology and therapy (p. 117). He argues that the intrinsic vulnerability and tragic character of human existence form the background and the place of origin (but not so much the necessary cause) that allows for and evokes the dynamics of evil (p. 118). Tragic existence entails vulnerability (injury, suffering death), competitiveness, worry, anxiety, the fragility of one's social world and self-conscious experiences of discontent (pp. 121-124). Farley observes that the differentiation between sin and tragedy is one of the seminal insights of the Hebraic tradition (p. 125). Evil is not a fateful inevitability but a contingent response to the anxiety and discontent that characterise tragic existence (pp. 126, 128). It is a response that seeks to overcome such vulnerability and to provide a securing foundation (e.g. through religion, science, art, the nation, institutions, social movements - p. 133). The desperate attempt to find something, anything that can remove the discontent and vulnerability of human existence through penultimate satisfaction is idolatry (pp. 134-135). Farley therefore insists that evil is a contingent response to tragic existence. He identifies at least three other

20 In another chapter Farley discusses the role of 'elemental passions' for survival and well-being, for interhuman confirmation and intimacy, and for a sense of reality. He argues that in the same way that self-assertion and even aggression form part of tragic existence (given the unbridgeable gap between desiring and the satisfaction of such desires) and cannot be equated to sin, desire (and a certain egocentrism) may become distorted through sin but cannot be equated with sin. Here too he resists a Manichean tendency to equate sin with the conditions of finitude and the desires and anxieties associated with being self-consciously finite (see p. 101 in conversation with Wolfhart Pannenberg). The passions are structured tragically but not evil (against Manicheism; they are nevertheless corruptible and corrupted (and not merely subject to pathology and redeemable though therapy - see p. 172). 
responses to tragic vulnerability, namely to regard vulnerability as pathological injury, to dull the discontent through various distractions and bravado. He thus resists contemporary tendencies to regard expressions of evil as a form of pathology (symptoms of stress, neurosis, phobias, syndromes, depression) that requires therapy for the somehow innocent perpetrators (p. 137).

In another chapter Farley explores the ways in which bodily life is corrupted through the sin of idolatry. He insists that being embodied is not the culprit for human life (as maintained in Manicheism), but that it can indeed be corrupted so that wickedness is not merely a sickness or pathology that requires therapeutic treatment (p. 212). He argues that our bodily needs and desires for food, comfort, survival, healing and sexual intimacy imply tendencies towards satisfaction and competition but that neither may be associated with sin. All these strivings are rooted in our biological make-up but are also shaped by symbolic language and culture. He adds that "Biologically rooted but culturally extended urges towards various satisfactions constitute the primary form of our natural egocentrism" (p. 214). Such egocentrism is associated with primary urges to maintain the integrity of life, the elemental passions and the subtle pleasures of human culture but are not sinful or evil, not even harmful. Given the fragility of the body, striving for also implies striving against various perils such as inclement weather, insects and bacteria and the predatory behaviour of other animals (p. 215). Farley acknowledges that we hunt, gather, harvest and kill for food and that we also compete with each other for food and also for mates, territory, status and rights with a degree of antipathy, anger and aggression (p. 215). However, he insists that "Being biologically equipped to oppose our own kind does not mean that our hormones and enzymes have fated us for murder and warfare" (p. 215). Such physiological equipment for opposition is not itself evil or the cause of evil. He concludes that "Because we desire well-being, we are ready to oppose, to have antipathy for those who would threaten our mate, our child, or our lives. And this readiness originates not from the dynamics of evil but our evolutionary heritage" (p. 216). Evil does not come from the impulses that our phylogeny has fostered on us (p. 216). Evil can co-opt bodily urges but such urges are not by themselves corrupt or even corruptible (in the same way that one's skeleton or lungs cannot become morally corrupted - p. 218). The corruption of biologically rooted desires has to do with reified cultural expressions of the frustration of such desires (p. 222). Our need for food does not determine what we eat, how much we eat, when and where we eat or in whose company we eat. Sin therefore remains contingent. Our bodily needs, drives and desires are not the cause of evil although these may at least be a sine qua non for the distortions effected by sin (p. 221). Wickedness does not flow directly from anger or aggression, but distorts that through stories, traditions and institutions of war, violence and revenge (p. 223).

In this way Farley defends what I describe as the contingency of evil. Pain, suffering and death form an integral part of life, as do self-affirmation, aggression and a certain egocentrism. However, cruelty, evil and injustice, while rooted in human capabilities are distortions of the human condition. Does Farley perhaps underestimate the violence embedded in acts of eating with his notion of tragic existence?

\section{Eating as Intimacy: A Kenotic Evolutionary Principle?}

We are not only genetically related to other forms of life but also dependent upon them. Although there may be competition for food and security among species and specimens, the very existence of food chains suggests an inter-dependence between species. As Thomas 
Berry suggests somewhere, this constitutes a form of intimacy, not enmity. Trillions of micro-organisms form a necessary part of our own bodies. We share the same space which other species inhabit. From before birth until after death we form part of an intricate food chain. Or in the words of Martin Versfeld: "Partaking of food is the partaking of reality."

This suggests the need to undermine binary oppositions regarding eating as if the absorption of food can be classified in terms of enmity and intimacy, what is inside and what is outside. When animals eat, they transfer energy derived from bacteria into another organism but in the process also feed numerous organisms living inside them. They themselves form part of larger ecosystems that are more fluid and interdependent than is often assumed. Our human bodies have porous boundaries, as eating and the excretion of body fluids indicate. This is illustrated precisely by intimacy - as is the case of mothers nursing babies, between lovers and in sport. It is therefore facetious to make clear distinctions between subjects and their bodies, materials and meaning. The food that we eat not only shapes our bodies, our moods and our self-image but also our physiology and in the long run, the evolution of our species. ${ }^{21}$ From the perspective of ecosystems it is not possible to identify discrete, individual organisms since the life of any one organism is intertwined with that of others. In the language of deep ecology the Self is not restricted to an individual self but to the emergence of Life itself. In the human species the evolving universe has to come to self-consciousness.

Sallie McFague (2013:21) refers to the example of a nurse log, i.e. lying down trees that have lived standing up for hundreds of years and now provide a nutrient-rich environment for young saplings to grow. The nurse log can live another several hundred years as the giver of new life. She concludes: "It all works by symbiosis - living off one another. Nothing in an old-growth forest can go it alone; nothing could survive by itself; everything in the forest is interrelated and interdependent: all flora and fauna eat from, live from the others" (2013:21). From this perspective, eating does not so much imply the killing of individual organisms but a transfer of energy through absorption and excretion to support the flourishing of the whole ecosystem.

On the basis of such a perspective a significant number of scholars in the field of ecotheology have detected a kenotic principle in evolutionary history - and indeed underlying cosmic history. ${ }^{22}$ The argument here is that evolution is not characterized only by competition towards the survival of the fittest but also by self-giving. This is already evident in the 'death' of stars since planets are made from the 'ashes' of 'dead' stars. It is especially characteristic of the death of individual living organisms that 'give' their bodies to become food for other organisms. It should be noted that kenosis is treated as a principle here. It is not a contingent response to the impact of evil (see below), but a description of "the moral nature of the universe" (Ellis and Murphy 1996).

A more nuanced treatment is found in Sallie McFague's Blessed are the Consumers (2013). Following Holmes Rolston (2001), she is careful not to identify a continuity of

21 One may even argue that cooking food played an important role on human evolution. Wrangham (2009) observes that humans are the only species that cook their food and that this had a profound evolutionary impact since it increased food efficiency and allowed our human ancestors to spend less time foraging for food.

22 There are too many scholars to mention here, but the volume edited by Polkinghorne (2001) certainly set the tone for others to follow. Besides the work of Sallie McFague discussed here, one may also mention contributions by Denis Edwards, George Ellis, John Haught and Christopher Southgate - who are involved in discourse on theology and the sciences 
kenotic tendencies in nature (p. 146). She recognises the role of competition and interdependence. Evolution is the process of life preying on life. Advanced life requires food pyramids; eating and being eaten (p. 146). If organisms 'sacrifice' their lives for others in their environment, this does not take place consciously: "it works in a self-interested fashion but within a system of interdependencies that demands "sharing"' (pp. 146-147). She adds that one cannot have life without losing it. To receive energy is at once to live and to kill other lives before they enter our mouths (p. 148). Inversely, all living creatures have to die and in the process contribute to the lives of others beyond their own. This is radicalised in the Christian faith which embraces a God who dies so that new life may be possible (p. 159). It is the power of love to let others be. With Dorothy Sölle she states that her wish is that creation should remain alive more than to remain alive herself while everything else should die to make that possible. McFague thus ventures to suggest:

What we love is not individual eternal life for ourselves so much as the continuation of the entire awesome, beautiful abundance of creatures, great and small, that causes us to gasp in wonder and thanksgiving that we have, at least for a short time, been a part of this glorious creation. We wish it to continue, not only in our nearest and dearest (our children, our tribe, our country and our species) but also in all the forms, from slugs to stars, that lie outside our daily appreciation but are necessary to the health of the whole (pp. 165-166).

On this basis McFague proposes a kenotic theology as a body theology through the sharing of scarce resources among the needy. It focuses on food as most basic need that organisms have for survival (p. 171). A kenotic theology, she says, "is not a lofty theology glorifying 'God or man'; rather it is a theology that begins with need, both God's need and ours, a need that runs all the way from the most elemental biological processes of the energy transformation to understanding the Trinity (the being of God) as one of continuous and total exchange of love" (p. 172). Life is only possible through the shared sacrifice of all for others (p. 185). Indeed when we die we become food for others and so we are "received back into the great sea of life and love which is God" (p. 186). Creation is about bodies, about flesh and food and therefore about the economics of just, sustainable sharing of the world's resources for all the needy (p. 198). To give oneself is ultimately to give one's body as food for other bodies in order to keep such bodies flourishing (p. 201). The kenotic love at the heart of the Christian faith is therefore captured by the symbol of food (p. 202). She says:

Food is the sine qua non of existence; it sums up the entire corporeal planet, which is created by energy and is sustained by food; the evolutionary story is the tale of who gets food and who does not; and wars increasingly will be fought over food. As we consider the dual crises facing our planet - climate change and unjust resource distribution - we see that they are all about food. If we take the mother-child relationship as a quintessential example of what we mean by compassion or empathy - responding to the deepest need of another - then the mother's giving food from her body to the infant can be seen as the model of radical kenotic love. It is no accident, then, that food appears so frequently in the Christian story and that its central ritual, the Eucharist, is a common meal in which the disciples give food to one another as Christ gave his body as bread and wine for all (p. 202).

On this basis McFague concludes:

The classic doctrine of Christian discipleship, that, made in the image of God, human beings should embody the kenotic love of God, means that our bodies must be on the line. In other words, food (and the whole planetary apparatus that goes to produce food 
for billions of creatures) should become the central task at all levels, personal lifestyle choices, and public policies (p. 203).

Although McFague seeks to avoid a continuity between kenotic tendencies in nature, the kenotic love of God and Christian discipleship, she does not regard kenosis as a contingent response to human sin. Instead, kenosis seems to be a self-conscious expression of a tendency also found in others forms of life that counter-balances the tendency towards aggressive self-affirmation found in eating by absorbing other living organisms. How should sin then be understood? McFague does discuss sin in several of her works, e.g. as "the refusal to accept our place", the refusal to know and to accept our limitations (1993:112) and therefore as the human encroaching on the space, the habitats of other species (1993:100-101). Salvation is then understood accordingly, namely in terms of the imitation of Christ's example of self-sacrifice. ${ }^{23}$ What it means to be a human being is simply to choose to be what one is: a participant in the God's very own life of love (McFague 2013b:31). She explains this in terms of a kenotic view of God:

Jesus' whole life was a lead-up of total giving to others, culminating in the cross where he sacrificed his life, not for the atonement of humanity's sins, but as a witness to the totally unexpected and overwhelming gift of God's own self as the answer to our questions about who we are and how we should live (McFague 2013b:29).

And:

We live by participating in God's very own life (since this is the only reality there is), but not simply as parts of God; rather, human life is learning to live into the relationality of God's own life, which is one of self-emptying love for others ... And, according to the kenotic paradigm, this is what 'salvation' is: not release from punishment for our sins, but a call to relate to all others (from God to homeless persons and drought-ridden trees) as God would and does (McFague 2013b:33).

\section{The Eucharist as a Contingent Self-sacrifice}

In his significant book entitle Food and Faith: A Theology of Eating (2011), Norman Wirzba responds to the degraded understanding of the meaning of food in advanced industrial societies where speed, convenience and cheap prices have become the most valued drivers in food consumption. He observes that eating has become thoughtless and irresponsible, lacking the sensitivity, imagination and understanding that come from growing, preserving and preparing food: "though everyone chews, relatively few eat with much understanding of or sympathy for the widespread destruction of the world's agricultural lands and communities or for the misery of billions of factory-produced chickens, sheep, pigs and cattle" (p. xiii). His focus is clearly on a critique of consumerist patterns in North America so that issues of food security and hunger are recognised but not

23 Elsewhere McFague (2013:23) critiques the classic Christian view of God's actions. She says: "This mythic story focuses on God's actions - God is the protagonist of the world drama - and ... speaks to our concerns about why the world was made, who is in charge of it, why it is no longer harmonious, and how it is made 'right' again. This story does not speak to our interest in the world or how we should act toward our neighbours. Human beings are, in fact, minor players in the classic Christian story of creation and providence. Moreover, the action does not occur in our physical neighbourhoods, the actual spaces and places we inhabit, but over our heads, as it were, in the vast panoramic historical sweep of time, with its beginning (creation), middle (redemption), and end (eschatology). In each of these events God is totally in charge; we, at most, like good children are grateful to our all-mighty, all-loving Father and try to follow his will. Even when sin and evil divert the drama from its triumphant course (and cause us to lose faith and hope), the lord of history will prevail, the king will be victorious. 
foregrounded (the term 'hunger' does not appear in the index!). In response he sets out to develop a theological vision of the ways in which we grow and taste food and of what eating is meant to be in the kingdom of God (p. xv).

To his credit Wirzba recognises from the outset that eating (for the sake of preserving life), also vegetarian eating, depends on death. Death is eating's steadfast accomplice (p. 1). There is no such thing as 'cheap' or 'convenient' food. Eating is a movement that takes place through the death of others and ends up in death. Wirzba says: "Eating is the daily reminder of creaturely mortality. We eat to live, knowing that without food we will starve and die. But to eat we must also kill, realizing that without the deaths of others - microbes, insects, plants, animals - we can have no food" (pp. 110-111).

Wirzba recognises that accepting the gift of life, to acknowledge that suffering and death accompanies every diet, is an extraordinarily difficult thing to do if one is conscious that this implies receiving the deaths of others. Nevertheless, Wirzba assumes that eating is not itself an effect or sign of a fallen creation, although eating takes on a different character after the fall (see p. 1, note 3). Eating reminds us that we are not self-subsisting gods, "that we participate in a grace-saturated world, a blessed creation worthy of attention, care and celebration" (p. 2). To receive food as a gift and as a declaration of God's love and joy is to understand food in a theological manner (p. 11). This, Wirzba believes, transforms the way we eat. Eating is not merely reducible to the consumption of others; we eat in order to share, sustain and nurture life, to accept responsibility for another's well-being. Eating implies hospitality, to enter into communion and to be reconciled with each other: "To eat with God at the table is to eat with the aim of healing and celebrating the memberships of creation" (p. 11). Food is a gift from God to be gratefully received and generously shared (p. 12).

This theological vision of eating implies that the goal of eating is not to worship food or to bow down before the modern idols of control, efficiency and convenience (p. 11). Where eating becomes idolatrous the result is degraded habitats, miserable animals, abused workers, unjust trade agreements and lonely eaters (p. 12). By contrast, through the spiritual consciousness of a prayer of gratitude, food ceases to be merely fuel or a commodity; "Eating becomes the sharing in and a sharing of the blessings of God" (p. 33). Eating places us within the garden and it within us (p. 59).

Wirzba treasures the image of a garden with God as the first Gardener and us as gardeners to indicate that sustainable food production is possible. This implies the recognition of boundaries. To live as if there are no boundaries is to claim to be a god (p. 75). To treasure one's membership of the garden that makes life possible is to acknowledge the responsibility to serve and protect the garden. To eat from the garden is to understand that we cannot thrive alone and that we depend on others for our sustenance and health (pp. 75, 109). Life itself is resurrection from the death of others - of chickens, chicory and chickpeas. To live is to be perpetually rising from the dead. To reject death is to reject the soil from which life comes forth (p. 133, drawing from Robert Farrar Capon).

If eating implies killing, how can one then eat without sinning? The message of the gospel does not address this speculative question. Instead, it responds to and transforms current destructive food patterns. How does that take place? In a chapter entitled "Life through death: Sacrificial eating" (pp. 110-143) Wirzba also draws on the concept of kenosis in order to place life and death in a Trinitarian perspective. The death of Jesus symbolises a life that gives itself completely for the sake of others. Biological death is therefore not an unqualified evil. Death is only evil if it becomes a force that degrades life 
and despises the gift of nurture, not when it follows a fulfilled life (p. 115). Good death is the kenotic passage through which life moves (p. 111). Physiological death is therefore not merely the expiring of bodily organs and the obliterating of an autonomous self. Viewed Christologically, "death is a self-offering movement in which the individual gives himself or herself to another for the furtherance of another's life... Rather than viewing life as a possession, the person inspired by Christ understands that life is a gift to be received and given again" (p. 112). In other words, by death (except in cases of cremation) one becomes food for other organisms on which one has been feeding. On this basis Wirzba can state that:

Creation is an altar on which creatures are offered to each other as the expression of the Creator's self-giving care and provision for life. To be made in the image of this Triune Creator is to be invited to share in the shaping of this world as an offering of love. The passage from death to genuine life is a loving movement of self-offering in which people lay down their lives for others in gestures of nurture and help (1 John 3:14-16) (p. 112).

Death understood as the failed attempt to prevent the extinction of the ego implies a refusal to participate in the community of life. For Wirzba this is what sin entails: self-enclosure and self-glorification (p. 114). It is a way of being "that represents a fundamental violation of what it means to be a creature in relation with others altogether dependent upon God. To $\sin$ is to refuse to receive the world as gift. It is to reject love as the means through which the gifts of food and life are perpetually transformed into offerings that nurture creation and bring glory to God" (p. 114).

In response, Wirzba retrieves a notion of sacrificial eating in order to help people understand that eating is a matter of life and death and to help turn Christian communities into more responsible, caring and grateful eaters (p. 116). Sacrifice is not a socially approved ritual to legitimise hunting and killing as a cathartic release of an aggressive instinct, but (for farmers) a form of self-sacrifice (giving up the best fruits that they have) in order to nurture a relationship with God (p. 119). It is best understood as an expression of gratitude before God. Wirzba explains:

No matter how resourceful we are, we are not the sources of our own or any other life. How should we receive and become worthy of the countless lives that are given as a means for our sustenance and good? When we ponder this question we discover an overwhelming disproportion between the extent and cost of gifts received and the human ability to adequately express gratitude for them. We sense a fundamental inability to comprehend our own experience as maintained and continually intersected by the living and dying of countless others... To offer food to another, especially the precious and costly food of animal flesh, is to acknowledge that life is not to be taken for granted or hoarded as a possession to be used however one wills... To offer food to another expresses a profound insight into the gifted and interdependent character of the human condition. In this offering people acknowledge that as creatures they are beneficiaries of an incomprehensible and costly generosity and hospitality... To share food is fundamentally to share life (pp. 120-121).

From such insights Wirzba seeks to develop a notion of Eucharistic sacrifice symbolised by the eating of bread and the drinking of wine. He captures the meaning of this meal for membership: "Eating, in other words, was the occasion in which Christ's followers could witness to his ongoing presence in the world. To remember Jesus is to join in a remembering of a world dismembered by sin" (p. 150). Indeed, the whole of creation may be regarded as "an immense altar upon which the incomprehensible self-offering love of God is daily made manifest" (p. 126). This is symbolised by the seed that has to die in the 
ground in order to bear fruit. This becomes the paradigm to understand the death and resurrection of Christ - which is also a pattern for Christian sacrificial living (p. 127). Wirzba thus concludes:

The food we consume is God's creation, a vast and unfathomably deep community of creatures that is sustained by God's sacrificial love. Every time we eat, we are called to recognize the profound mystery that God created a world that, from the beginning (even in something like a pre-fallen state), lives through the eating of its members (p. 134).

It should be clear that Wirzba, like McFague, employs the category of kenosis to come to terms with the consumption of food and becoming food for others. However, he does not treat kenosis as a cosmic moral principle since he links it much stronger to the sacrificial death of Jesus Christ and the resurrection of new life in Christ. This is necessary and possible given a sharper distinction between creation and fall. Life and death, eating and being eaten, killing other forms of life to eat and giving one's own body to be eaten by others, form part and parcel of God's good creation and should not be regarded as macabre or understood in a Manichean way. Feasting is the joy of life if appreciated with gratitude, hospitality and mercy and not gluttony, not taken for granted or exploited (p. 141). Sacrificial, Eucharistic eating is then a Christian response to the distortions associated with the production of food through commercialised agriculture and the consumption of food in a consumerist society (pp. 144-178). Eating bread and drinking wine involves relatively little violence - which encourages us towards a lifestyle that minimises violence although it cannot be completely avoided. It transforms eating in general so that it can become hospitable at its core and lead to a communion of life (p. 149).

In a somewhat macabre sub-section Wirzba (while noting the criticism that early Christians were cannibals) speaks of 'eating Jesus'. He explains that there is a physiological form of eating in which the other is absorbed into me to meet my nutritional needs so that I can live. However, 'eating Jesus' takes place in such a way that Jesus 'abides' in us (John 15). In this case the other is not absorbed in me (signalling the end of a relationship) but remembered and hosted so that I "invite and welcome them to enter into my affective and moral imagination, and so I am transformed from within. With this kind of eating I am inspired, corrected and nourished by the other without the order being completely destroyed" (p. 157). 'Eating Jesus' results in the mutual indwelling that Paul describes as Christ dwelling in me. In a sense (drawing on Bernard of Clairvaux) we are also 'eaten by Jesus', even chewed and digested, breaking down what was eaten, so that we can be transformed by Jesus from within and thus become the food that nurtures the world and so that we can celebrate and embrace the world as given by God (pp. 160-161). Wirzba links the process of eating (or being eaten by Jesus), chewing, absorbing nourishment and excreting what is harmful with the dialectic between cross and resurrection: "Resurrection life, the life that is true, abundant and eternal, goes through the crucifixion. When people are properly chewed by Christ, that is, when they are properly corrected, instructed and trained by Christ, this sin that divides and harms the body is destroyed so that each member can serve the other with a spirit of sympathy and gladness. With the destruction of sin we can become the nutritious food that will heal and strengthen the world" (p. 162).

Wirzba clearly blends the physiological and metaphorical meaning of eating here, but given his own focus on appropriate forms of nourishment, one wonders whether such 'abiding' would not lead to indigestion or constipation! He argues that "when people eat as those trained at the Eucharistic table, no life is simply fuel to be absorbed. All life becomes a sign and sacrament of God's love, a witness to the costliness and mystery of life and death, and so becomes the inspiration to greater attention and care" (p. 158). However he 
adds that "The opening through which another is welcomed into my mouth and life is also the opening through which my life is moved to respect and respond to what is other than me - starting with the humble word of thanks, but then extending to the implementation of food economies that care for life" (p. 158). This should lead to the virtues of gratitude and hospitality, but since the meaning of food as nourishment returns here, one has to ask whether such eating does not still involve killing the other, even if this is qualified by grateful remembrance. ${ }^{24}$ Are the evolutionary roots of violence overcome by saying that "whenever we eat, those we eat and those we eat with will have been welcomed and cherished as manifestations of God's love" (p. 178)?

This begs the question of how eating is understood eschatologically. Will there be eating in heaven? Will resurrected bodies eat? To his credit Wirzba addresses such question in the final chapter of his book. He is clearly still aware that eating vegetables and meat involves some form of 'violence' (killing other metabolisms), but also appreciates that eating is a symbol for hospitality and intimacy - in the gospel narratives and in agrarian communities alike. If the whole of creation manifests God's primordial hospitality, then this has to apply also eschatologically. He therefore assumes that there will indeed be eating in 'heaven' and speculates that such eating will not necessarily imply consuming and destroying other forms of life - in the same way that the presence of God in the burning bush did not 'consume' the bush (Exodus 3:2). If eating implies intimacy, then it requires responsibility and affection for the other. So Wirzba concludes: "Eating is about accepting the reality of another - its life and death, its history of struggle and success, its dignity and grace - into our lives, into our mouths, into our bodies, and into our stories and hopes" (p. 233). To enjoy a proleptic foretaste of heaven is to participate in a Eucharistic community where people live lives based on sacrificial self-offering, grateful reception and reconciled relationships (p. 234).

\section{An Inconclusive Postscript}

Is the violence associated with sin merely an extrapolation of the 'violence' embedded in the act of eating? All three the main authors selected for discussion in this essay would deny that this is the case. All three accept that death, eating and killing form part of parcel of the evolution of life on earth. Evil is then best understood as a radical distortion of the cycle of eating and being eaten. Sin is a contingent response to the conditions of creaturely finitude that has had disastrous consequences. This leaves one with the question of how to interpret such 'violence' (terminating other metabolisms) associated with most acts of eating (except perhaps for eating fruit, nuts and seeds).

The three selected authors follow rather different strategies in this regard. Farley employs a notion of being a finite creature in order to recognise a 'tragic' dimension in human existence. That is not to be equated with evil so that the dialectic between sin and salvation is focused on the tension between idolatry and (in his terminology) 'being founded' (Farley 1990:139-153). McFague finds a kenotic principle at work in being eaten and suggests that this principle overrides the violence that may also be found. She regards this kenotic principle as core to the ethos promoted by the gospel. Being eaten therefore has salvific significance if that allows ecosystems to flourish. Wirzba also acknowledges the need for kenosis but understands that Christologically in terms of a conscious (and

24 One is reminded of an old joke here: In the African savannah a tourist is chased by a lion. Panicking, the tourist prays: "God, please grant that this would be a truly pious lion." The prayer is answered. The pious lion kills the tourist and then prays: "For what we are about to receive, Lord, make us truly thankful." 
contingent) act of sacrifice in response to the 'violence' embedded in eating (which he recognises quite acutely). He imagines that such violence will be removed from eating eschatologically, even though this cannot be imagined protologically.

Does any one of these strategies avoid either a Manichean or a Pelagian assessment of the human condition? ${ }^{25}$ Is there not something cooperative and something aggressive in all forms of eating? If so, are we to be saved from part of our own genetic heritage? Do we have to save ourselves (and the Earth) by minimising violence and enhancing a spirit of cooperation? What would this mean for human eating habits? The conclusion seems to be that an Augustinian approach is indeed less plausible and more counter-intuitive than Manichean or Pelagian assessments of where things have gone wrong in evolutionary history. If so, it seems that we cannot avoid fluctuating between Manichean pessimism (we have to eat and will be eaten) and Pelagian optimism (in eating and being eaten we can maintain the virtues of hospitality and reciprocity).

If we indeed have to acknowledge a mixed evolutionary heritage that includes both a need for violence and a need for cooperation, then the contemporary food industry can claim some continuity with pre-human and early human evolution. It is indeed a collaborative enterprise on a gigantic scale that produces more food than ever before, although it comes at the price of skewed distribution amongst humans and considerable environmental costs. One may then seek to minimise the embedded structural violence, including unnecessary suffering for sentient animals, but the violence embedded in evolutionary history in the form of killing for food cannot be avoided. The danger here is that one may all to easily claim that the violence of industrialised capitalism is an extrapolation of our evolutionary heritage.

One may observe that such violence can indeed be minimised through appropriate human habits but that carnivores can scarcely be eliminated from evolutionary history. One may of course reserve the term 'violence' for actions with evil intention and then argue that eating by itself does not entail such violence. Eating does entail killing (absorbing other living organisms so that they no longer exist as discrete metabolisms), but that takes place in the interest of allowing life to flourish. Distinct metabolisms do exist but only within the context of larger ecosystems where absorbing another or becoming integrated in another is not a sign of death but of the flourishing of life within ecosystems. Either way, my attempt in this contribution is to test the distinction between natural suffering and socially-induced suffering without seeking escape routes from the 'violence' that is embedded in evolutionary history, ensuring that the test is made as hard as possible. One may rightly wish to emphasise the discontinuity between the violence associated with predation and inter-human violence, but the focus here was on assessing the significance of the continuity between biological evolution and cultural evolution.

I need to add that I truly hope that such conclusions are wrong both on logical and on theological grounds. I therefore submit these inconclusive observations in the hope of being corrected by other scholars working in the field.

25 Robert Williams (1985:196) astutely observes on the eclipse of the Christian doctrine of sin and the contemporary interest in the problem of evil that "Modern culture presents a generally secular view of evil with optimistic and pessimistic variations. It is of particular theological interest that the types of views concerning evil against which classic Christian thought struggled - the optimistic Pelagian view and the pessimistic Manichean view - have tended to displace the Christian doctrine of sin." 


\section{BIBLIOGRAPHY}

Bimson, John J 2006. "Reconsidering a 'Cosmic Fall”". Science \& Christian Belief 18:1:63-81.

Brink, Gijsbert van den 2011. "Should we Drop the Fall? On Taking Evil Seriously". In: Van der Borght, EAJG (Eddy) \& Van Geest, Paul (eds.): Strangers and Pilgrims, 761-777. Leiden: Brill.

Conradie, Ernst M 2005. Hope for the Earth - Vistas on a new Century. Oregon: Wipf \& Stock.

Conradie, Ernst M 2006. "On Responding to Human Suffering: A Critical Survey of Theological Contributions in Conversation with the Sciences". In: Du Toit, Cornel W (ed.): Can Nature be Evil and Evil Natural? A Science-and-Religion View on Suffering and Evil, 165-188. Pretoria: Unisa.

Conradie, Ernst M 2013a. "Darwin's Ambiguous Gift to Reformed Theology: The Problem of Natural Suffering and Calvin's Meditation on Future Life". In: Van der Belt, Henk (ed.): Restoration through Redemption: John Calvin Revisited. Studies in Reformed Theology 23:95-112. Leiden: Brill.

Conradie, Ernst M 2013b. Saving the Earth? The Legacy of Reformed Views on "Re-creation". Studies in Religion and the Environment Vol. 8. Berlin: LIT Verlag.

Conradie, Ernst M 2015. The Earth in God's Economy: Creation, Salvation and Consummation in Ecological perspective. Studies in Religion and the Environment Vol. 10. Berlin: LIT Verlag.

Drees, Willem B (ed.) 2003. Is Nature ever Evil? Religion, Science and Value. London: Routledge.

Durand, JJF (Jaap) 1978. Die Sonde. Pretoria: NGKB.

Edwards, Denis 2014. Partaking of God: Trinity, Evolution, and Ecology. Collegeville: Liturgical Press.

Ellis, George FR \& Murphy, Nancey 1996. On the Moral Nature of the Universe: Cosmology, Theology, and Ethics. Minneapolis: Fortress Press.

Farley, Edward 1990. Good and Evil: Interpreting a Human Condition. Minneapolis: Fortress Press.

Gestrich, Christof 1995. The Return of Splendor in the World: The Christian Doctrine of Sin and Forgiveness. Grand Rapids: WB Eerdmans.

Grumett, David \& Muers, Rachel 2010. Theology on the Menu: Ascetism, Meat and the Christian Diet. London: Routledge.

Hefner, Philip 1993. The Human Factor: Evolution, Culture and Religion.

Minneapolis: Fortress Press.

Jonas, Hans 1966. The Phenomenon of Life: Towards a Philosophical Biology.

Evanston: Northwestern University Press.

Jüngel, Eberhard 1971. Tod. Stuttgart: Kreuz Verlag.

McFague, Sallie 1993. The Body of God: An Ecological Theology. London: SCM Press. McFague, Sallie 2013a. Blessed are the Consumers: Climate Change and the Practice of Restraint. Minneapolis: Fortress Press. 
McFague, Sallie 2013b. "Falling in Love with God and the World: Some Reflections on the Doctrine of God". The Ecumenical Review 65:1:17-34.

Midgley, Mary 1978. Beast and Man: The Roots of Human Nature. London \& New York: Routledge.

Northcott, Michael 2007. A Moral Climate: The Ethics of Global Warming. Maryknoll: Orbis Books.

Plantinga, Cornelius 1995. Not the Way it's Supposed to Be: A Breviary of Sin. Grand Rapids: WB Eerdmans.

Polkinghorne, John (ed.) 2001. The Work of Love: Creation as Kenosis. Grand Rapids: WB Eerdmans.

Rolston, Holmes III 1994. “Does Nature Need to be Redeemed?” Zygon 29:2:205-229.

Rolston, Holmes III 2001. "Kenosis and Nature". In: Polkinghorne, John (ed.): The Work of Love: Creation as Kenosis, 43-65. Grand Rapids: WB Eerdmans.

Ruler, Arnold A van 2008. Van Schepping tot Koninkryk (edited by Gijsbert van den Brink \& Dirk van Keulen). Barneveld: Serie Klassiek Licht.

Versfeld, Marthinus 1983. Food for Thought: A Philosopher's Cook-book. Cape Town: Tafelberg.

Wallace, Mark I 2010. Green Christianity: Five Ways to a Sustainable Future. Minneapolis: Fortress Press.

Williams, Robert R 1985. "Sin and Evil”. In Hodgson, Peter C \& King, Robert H (eds.): Christian Theology. An Introduction to its Traditions and Tasks, 194-221. Philadelphia: Fortress Press.

Wirzba, Norman 2011. Food \& Faith: A Theology of Eating. Cambridge: Cambridge University Press.

Wrangham, Richard 2009. Catching Fire: How Cooking made us Human. New York: Basic Books. 